MANAGEMENT, ORGANIZATIONS AND CONTEMPORARY SOCIAL THEORY ${ }^{1}$

Stewart Clegg

Miguel Pina e Cunha

${ }^{1}$ Miguel Pina e Cunha acknowledges support by National Funds through FCT - Fundação para a Ciência e Tecnologia under the project Ref. UID/ECO/00124/2013 and by POR Lisboa under the project LISBOA-01-0145-FEDER-007722. 
TABLE OF CONTENTS

\begin{tabular}{|c|c|c|}
\hline 1 & $\begin{array}{l}\text { Management, Organizations } \\
\text { and Contemporary Social } \\
\text { Theory }\end{array}$ & Stewart Clegg \& Miguel Pina e Cunha \\
\hline 2 & $\begin{array}{l}\text { Andrea Whittle \& Frank } \\
\text { Mueller }\end{array}$ & Etnomethodology \\
\hline 3 & Damian O'Doherty & $\begin{array}{l}\text { Actor-Network Theory: Michel Callon, Bruno Latour, John } \\
\text { Law }\end{array}$ \\
\hline 4 & $\begin{array}{l}\text { Ira Chatterjee, Jagat Kunwar } \\
\text { and Frank den Hond }\end{array}$ & Giddens and structuration theory \\
\hline 5 & Alistair Mutch & $\begin{array}{l}\text { Morphogenesis and reflexivity: Margaret Archer, critical } \\
\text { realism and organizational analysis }\end{array}$ \\
\hline 6 & $\begin{array}{l}\text { Mairi Maclean and Charles } \\
\text { Harvey }\end{array}$ & Pierre Bourdieu and Elites: Making the Hidden Visible \\
\hline 7 & $\begin{array}{l}\text { Georg Loscher, Violetta } \\
\text { Splitter and David Seidl }\end{array}$ & $\begin{array}{l}\text { Theodor Schatzki's theory and its implications for } \\
\text { Organization Studies }\end{array}$ \\
\hline 8 & $\begin{array}{l}\text { Dean Pierides and Graham } \\
\text { Sewell }\end{array}$ & Mary Douglas and institutions \\
\hline 9 & $\begin{array}{l}\text { Cátia Miriam Costa, Tiago } \\
\text { Lima Quintanilha and } \\
\text { Sandro Mendonça }\end{array}$ & Manuel Castells and Informationalism \\
\hline 10 & Xavier Deroy & Luhmann and Organizations as Social Systems \\
\hline 11 & Alan McKinlay and Eric & Organizing Foucault: Power, Knowledge and \\
\hline
\end{tabular}




\begin{tabular}{|l|l|l|}
\hline & Pezet & Governmentality \\
\hline 12 & Edward Granter & The Frankfurt School and Critical Theory \\
\hline 13 & Kate Kenny & Judith Butler and performativity \\
\hline 14 & Robert van Krieken & Norbert Elias and Organizations \\
\hline 15 & Stewart Clegg \& Miguel Pina & Liquefying modernity: Zygmunt Bauman as organization \\
& e Cunha & theorist \\
\hline 16 & Miguel Pina e Cunha \& & Management, organizations and contemporary social \\
& Stewart Clegg & theory: An index of possibilities \\
\hline
\end{tabular}




\section{MANAGEMENT, ORGANIZATIONS AND CONTEMPORARY SOCIAL THEORY²}

\section{Exploring social theory}

Social theorists speculate about large-scale social questions. A key focus is to ask of any phenomenon, how is it possible? The phenomena to which this question may be addressed include not only those phenomena that we may encounter in everyday life and practice, such as organizations and management; they also include explanation of these as a phenomenon. In this sense, what social theory addresses is how any social order or practices of ordering are possible. These practices thus include those constructing and those and that which are constructed through these processes. For example, social theory is concerned with how prior theories of the social, in their explanations of important questions, such as the nature of power and social structure, gender and ethnicity, modernity and postmodernity, civilizations and their discontents, have been formulated in the past and require contemporary reformulating in analytic terms for present knowledges and times. Contemporary social theory laces through all the concerns of contemporary management and organization theory: it offers not so much theory for management or theory for organizations but theory that is addressed not only to the social practices that constitute these theories but that also has implications for what these theories take for granted.

Management and organization theory are relatively recent areas of evolution in the social sciences; indeed, for the most part they evolved from earlier periods of embeddedness in broader social science areas such as sociology, history, economics or engineering. The

\footnotetext{
${ }^{2}$ Thanks to Marco Berti and Chris Carter for advice on earlier drafts of this chapter.
} 
founders of these areas were people such as Adam Smith (1950; lived 1723-1790), a political economist and moral philosopher; Karl Marx (1976; lived 1818-1883), also a political economist as well as a philosopher; Max Weber (1978; lived 1864-1920), a legal scholar, economic historian and latterly a sociologist; Frederick Taylor (1911; lived 1856 -1915), not a scholar but a self-taught engineer.

As the fields of management and organization theory have subsequently developed these disciplinary areas have become ever more specialized and those founders of the fields have largely faded from memory. Nonetheless, the big picture and large-scale theorizing that some of these figures engaged in (Taylor hardly counts in this calculus) has not faded away; there are many contemporary figures who approach larger questions of social, political, cultural and economic life, the power of whose thought has influenced broader theorizing about more specialized areas, including management and organization theory. Broadly speaking, those figures are recognized as social theorists because they have developed narrative and analytical frameworks that critically examine social phenomena. To say they do so 'critically' is the key: what they do not do is take for granted either how the field of knowledge has been constructed before them or accept the commons sense definitions of those phenomena that they are interested in.

What qualified a scholar to be considered a social theorist? Essentially, they are figures whose influence extends well beyond their home disciplines into the public sphere, combining the role of social theorist with that of being a public intellectual, someone that the educated non-specialist might come across, people whose ideas about the way that aspects of the world work have made a broad critical conceptual impact on that world: they make a difference as to how we see and think about our world. Making a difference is what 
great teachers do and we may say that the figures we have selected are all, through their books (and it is largely through books), figures who have made a significant difference to the way many others and we see the world. In this respect, they are heirs to the traditions that figures such as Marx, Smith or Weber initiated.

Let us consider Weber for a moment because he is an illustrative case of what makes a social theorist a social theorist. In management and organization theory, if he is remembered at all, it will most often be as classical theorist, concerned with bureaucracy. While this is not false it is hardly adequate: Weber was a major intellectual figure in debates about methodology, the origins of capitalism, the comparative study of major world religions, the ethics of vocation, economic history, the conditions of industrial workers, public administration and much else besides. What most management and organization theory know of him is very little. Consequently, what most students in these areas learn is even less. We may take from this founding example of Max Weber that social theorists are wide-ranging in their concerns; concerned with major intellectual debates that have contemporary relevance; concerned with delineating elaborated and coherent theory about the matters that debate encompasses and that they do so in such a way that they offer potential guidance to many substantive fields of knowledge.

Management and organization studies constitute a flow of knowledge fed by many streams, not all of them deemed social theory but nonetheless significant. Cybernetics, for instance, especially the contributions of Herbert Simon (1996; 2013) (a scholar awarded the Sveriges Riksbank prize in honor of Alfred Nobel) has played an important role. It is appropriate to state that the reason for the exclusion of Simon and (and of other important intellectual figures who greatly contributed to the development of organization theory, such as Gregory 
Bateson, [2000]) is not due idiosyncratic preferences but rather to the decision to focus on social theory informed contributions.

Social theory, as distinct from management or organization theory, is a continent of possibilities composed of many fields, with distinct but different topographical features. Social theory is concerned with the continent, with the overarching embeddedness of the distinct topographies of the different regions, or disciplinary areas. The effects of considerable evolution, erosion and accretion will have shaped some aspects of these disciplinary areas; other areas may be more recent, less sedimented, still being shaped. Social theory has been a major factor in the shaping, forming and evolving of these more recent substantive disciplinary areas, such as management and organization studies. The role of social theory produces very different inflections. Consider the ranking of Weber and Foucault, for instance. ${ }^{3}$ Comparing leading European production of disciplinary knowledge in the journal Organization Studies with that of the American journal Administrative Science Quarterly, Üsdiken and Pasadeos (1995) demonstrated that while Weber and Foucault loomed large in citations in the European consciousness, Foucault did not receive citation and Weber barely registered in America in the top 100 citations. ${ }^{4}$ The findings in this work are updated in Üsdiken (2014), which finds that differences between North American and European scholarship are still evident, looking at a broader range of journals and a longer period of time. Üsdiken (2010), in a related article, notes that perhaps as a result of national education systems' evaluation exercises that tend to privilege US-based journals, 'wholesale adoption of US-based theories and research practices has also been expanding' (Üsdiken,

\footnotetext{
${ }^{3}$ Carter (2008) suggests that the ranking for Foucault is a 'curiously British story' of a French philosopher and historian of ideas being embraced by British business school scholars in a way that their French counterparts, on the whole, did not.
} 
2010, p. 732). At the earlier stage there was a big difference but now American work is increasingly prevailing, re-framing European work through a combination of demographic density and intellectual hegemony through overwhelming command of the circuits of power - editorial and review functions in the key journals - that define legitimacy. Nonetheless, discernible differences remain. For the future, one should not think that building only on European intellectual traditions is the best way. Similar advances could (and should) be achieved by building also on other philosophical and social traditions developed outside of Europe, for instance from Chinese scholarship (Fei, 1939) or from the critical pedagogy of Brazilian Paulo Freire (2018) or from indigenous perspectives such as Mbigi (2005; see Seremani \& Clegg, 2015, on epistemological third spaces).

The disciplines, by convention, are textually composed networks: who gets cited where, when, how often, defines the disciplinary field. One of the things that social theory can do is to address how the texts of disciplinary scholarship and more everyday practices have been formed, shaped and used. Any such engagement is inherently critical in its questioning of existing institutions constituting the management and the organization of our selves and those things with which we live and work, the norms and practices established, their constitution of and by power and other disciplinary practices, such as writing, culture, politics, selfhood and technology.

The focus on social theories is not to deny the existence or significance of more organization or management-oriented writers such as those who regularly appear in the pages of the leading journals in these fields. Such figures are clearly significant. However, their significance remains largely specific to the management and organizations field: Karl Weick (1995) or Katherine Eisenhardt (1989), for instance, are clearly major figures in management 
and organizations but they are of less influence in terms of the development of broader social theories. While these figures are important they are not the focus here.

Our cast of characters have had a more transcendental impact, including on the practices of the management and organization disciplines, yet they will rarely be encountered in the undergraduate curriculum. The more advanced curriculum, however, is another matter: here the concerns, at best, are less with techniques and their application and more with what these techniques and applications do as practices. To ask these questions is to, necessarily, engage with social theory and in so doing, the student is engaging in a conversation that is much broader and potentially richer than those that may have been previously encountered. Such conversations are not easy at first; one is entering into the domains of scholarship that are well established, legitimate but contested, broad reaching and widely engaged. The question is where to begin: this book provides answers.

There is a considerable gap between what is typically taught in undergraduate business subjects and what is expected from research students. While the former courses are oriented towards producing technically competent managers, accountants, etc., the latter is more concerned to contribute original knowledge to the disciplinary corpus. An obstacle in this respect is the absence of a bridging text that covers aspects of contemporary social theory relevant to the world of business and organizations. Without grounding in social theory, research students are unlikely to gain the knowledge, skills and sophistication that will see them publish in the top tier journals. The intent of this book is to help students and their teachers in bridging this gap.

\section{The cast of characters}


As we have said, social theory is a rich and encyclopaedic domain. One must need to be selective. What guided the selectivity in this instance? The personal knowledge, particular enthusiasms and social networks of the editors framed a large part of it. We all have our favourites and those theorists that are represented here are some personal favourites, drawn from the stocks of knowledge that we use and deploy. Obviously, our knowledge is a form of 'bounded rationality'; it is framed by preferences, habits and theoretical orientations. We make no apologies for having these and being candid about them, for it is impossible to be exhaustive. No one can claim perfect knowledge or disinterest; hence our interests and our bounded knowledge frames the choices made. We had one implicit rule in making our choices, which was that the social theorists chosen should be ones with a relatively contemporary relevance and output. In practice, this means that they should have been writing in the period from the contemporary flowering of social theory from the 1960s to the present day.

The first chapter, written by Andrea Whittle and Frank Mueller, on 'Ethnomethodology', explores the influence of Harold Garfinkel and the approach to studying social action known as ethnomethodology. The chapter explores the distinct approach to studying organizing 'as it happens' developed by ethnomethodologists. Ethnomethodology was regarded as a quite radical approach when it was first encountered in Garfinkel's work because of its very evident difference from the dominant social theory of mainstream structural-functionalism. Its opposition to much embedded intellectual capital did not endear it those whose capital it was. The dominant theory, with its stress on systems, their functional prerequisites and pattern variables, on the centrality of socialization and social order within the frame of a central value system, could not have been more antithetical to the social theory that 
ethnomethodology established. Where the former was top down and emphasised social order, the latter was very much a theory that worked from the intricacies of how order was established provisionally and capable of being easily breached in scenes drawn from everyday life: from decision-making by jurors, presentations of self in critical performances of transgender identity, scenes drawn from shopping, counselling and so on. Order, instead of being a monolith that is obeyed by the many and disobeyed by the few that are deviant, is instead something that is co-constructed on the basis of many tacit assumptions, cues and conventions.

Garfinkel's ethnomethodology has been indirectly influential in an important strand of management and organization theory. Karl Weick's (1995) approach to sensemaking, developed from his earlier concern with The social psychology of organizing (1969 edition, especially), clearly learnt a lot from ethnomethodology. Indeed, one of us on occasion, has been known to refer to the sensemaking literature as ethnomethodology translated into management. That translation was not the extent of the use to which ethnomethodology was put.

Far from the Californian campuses where ethnomethodology first flourished its influence was felt in Europe, especially in the École Nationale Supérieure des Mines in Paris, where, as Damian O'Doherty writes in the chapter on 'Actor-Network Theory: Michel Callon, Bruno Latour, John Law', the three main protagonists of the approach, translated, in part, ideas from ethnomethodology into Actor-Network theory. Actor-Network theory (ANT) has become one of the most popular reference points across many regions of the social sciences and beyond. Moreover, it has become one of the most important approaches to management and organization, being 'applied' or extended by many well-known figures in 
the field, such as John Hassard (Alcadipani \& Hassard, 2010; Law and Hassard, 1999), Barbara Czarniawska and Tor Hernes (2005). Elements of the ANT approach have also been cited as an influence and synthesised by other branches of social theory. As with ethnomethodology, ANT starts from the actors and their doings rather than seeing them as 'cultural dopes' dominated by social systems that constrain them. One of the major innovations of ANT is to extend the notion of the actor, however. It is not only people that can exert social agency, that can act: actants, things that are non-human, such as technologies, as well as devices humble and smart and non-human beings such as scallops, also have agency in ANT. In a nutshell, ANT's main contribution is to regard the 'social' as the partial and contingent outcome of specific actor-networks construction and understanding of the things of everyday practices. These practices are situated: they take place in field trips, in laboratories, in the accounts that scientists write of their practices (which does not always coincide with that these scientists are observed as doing by ANT observers) and they involve not only many other actors in networks of action but also actants. The test tube must be sterile; the acid pure, the vacuum chamber pristine for science to work. These humble material things are all actants. As it is in science so it is elsewhere: the lecturer depends on material actants such as computers, software such as PowerPoint, video projectors and seven simpler things such as electric cables and connections. The agency that emerges is a collective and relational phenomenon in which the properties of both actants and actors form assemblages that are responsible for what is done.

Garfinkel's ideas not only influenced 1970s Parisian intellectuals such as Bruno Latour and Michel Callon, as well as the Englishman who worked closely with them, John Law; they also 
made headway in the hallowed halls of Cambridge, where a prolific social theorist, Anthony Giddens, had made a name for himself through numerous publications as the foremost interpreter of the sociological trinity of founding fathers, Karl Marx, Max Weber and Emile Durkheim (Giddens, 1973). Having done this, in 1976 he turned his imagination to establishing some New Rules of Sociological Method, in which a rich mix of philosophical and sociological resources were drawn on to produce what became known as structuration theory, a mix in which a little ethnomethodology was clearly discernible.

New Rules of Sociological Method marked a shift in direction in Giddens' preoccupations from classical to contemporary social theory. Ira Chatterjee, Jagat Kunwar and Frank den Hond, in their chapter on 'Giddens and structuration theory', discuss some of the major works that followed. What characterized these works was a concern with the duality of structure as a set of social relations and institutions framing social action by human agency. The concern with the duality of structure was not uppermost in either ethnomethodology or ANT, even though the relationship between individual action and social structure had long been a central topic in social theory. Anthony Giddens sought to reconcile the opposition between structure and agency which existed between the older focus of structural functionalism and the newer foci of approaches such as ethnomethodology and other approaches that were less inclined to constitute structure a priori.

Giddens' structuration theory regarded structure and agency as mutually constitutive, not as a dualism but as a duality. As a coin has two faces but is indubitably one thing so it was with social action, according to Giddens. Structure, in the form of institutions, rules and resources influences social action but the traffic is clearly not one way. Human actors are capable of changing the social structures they inhabit; moreover, that they can do the things 
they do is in part attributable to those structures they inhabit that enable certain kinds of action, as well as constraining other kinds of action. Structures are simultaneously always being (re)constituted through the actions that unfold. There is, in other words, a dynamic relationship between individual action and social structure that is played out empirically in what actors do. Giddens' theory of structuration seeks to explain the motivations for actions, the choices-real and perceived-that are afforded as structural opportunities and constraints framing the interactions, doings and practices that unfold.

Giddens' theory of structuration is not the only contender in the arena of social theory that seeks to formulate the relationship between structure and agency. As Alistair Mutch discusses in the chapter on 'Morphogenesis and reflexivity: Margaret Archer, critical realism and organizational analysis', Margaret Archer also paid considerable attention to these relationships. In this work she provides a framework for examining relationships between agency and structure that are applicable to organizations. Archer draws on a specific philosophical approach known as critical realism. Roy Bhaskar (1975) and Harré and Madden (1975) first developed the ideas of critical realism. Crucial to the position was that things in themselves have what Harré and Madden termed as causal powers, a position that Bhaskar named as transcendental realism. That science was possible, argued Bhaskar, was only because scientists could contrive experiments in which the real, manipulable nature of things could be actualized to produce particular outcomes. Under the appropriate standing conditions, designed in the laboratory, the causal powers inhering in things could be revealed, argued Harré and Madden. As a philosophy of science this is quite distinct from the more usual claim that science consists of observing the relationship between cause and effect in terms of events that are coterminous variables. Instead, it proposes that certain 
causal mechanism may inhere in the nature of things: for instance, iron will rust if exposed to the elements of air and water; causality may be genetic rather than eventful; it may be historical rather than coterminous. Whilst empiricism and positivism locate causal relationships at the level of coterminous events, critical realism locates them at the level of generative mechanisms rather than a coincident relation between dependent and independent variables.

Critical realism prescribes social scientific method that seek to identify the generative mechanisms producing social events while recognizing that socially constructed structures are subject to more change than the phenomena of natural science. Human agency is enabled and constrained by social structures that they reproduce or transform. Social structures are designed and can be changed - a practice facilitated by the findings of social research. Archer terms this capability agential reflexivity. Drawing on critical realism Archer engages in significant dispute between critical realists and structuration theorists. The chapter explores the relationship between Archer's work and the theory of institutional logics, to argue for the greater value of Archer's less deterministic approach than that of the typical institutional logician.

Pierre Bourdieu, a sociologist, anthropologist, philosopher, and public intellectual, conducted his original fieldwork amongst the Berber of North Africa but became an acute observer of the society in which he resided, that of postwar France. Bourdieu brought an eye for ethnographic detail and an appreciation of the social constructions of a world of significations, stratifications and symbolism that great anthropologists respect. As Mairi Maclean and Charles Harvey acknowledge in their chapter on 'Pierre Bourdieu and Elites: Making the Hidden Visible', Bourdieu was able to reveal and make manifest the hidden 
mechanisms of social stratification that often remain invisible in organizational and social life. The facility to do this was, perhaps, nowhere better displayed than in his book, Distinction: A Social Critique of the Judgement of Taste (Bourdieu, 1984), a book which relentlessly examines the cultural mores of French, more especially Parisian, life. Bourdieu's major contributions were many: he outlined a theory of practice that clearly influenced Giddens as well as Schatzki; he played a major role in debates in the sociology of education but for Maclean and Harvey his major contribution for the study of organizations and management was in his analyses of elites, their power relations and how they reproduce their social domination. In the chapter Bourdieu's ideas and concepts are used to illustrate four specific areas of research. These are class domination and its relation to cultural reproduction in big business; the importance of reflexivity for social mobility; how entrepreneurial philanthropy legitimates wealth; how distinctions, based on subtle and cultivated displays of taste, serve to stratify and exercise power. Bourdieu's work makes available resources for analysis of the activities of elites in the global field of power as they enjoy their undoubted domination, sometimes subtly so, other times more overtly.

Bourdieu was one of the earliest social theorists of practices per se, in his book, Outline of a Theory of Practice (Bourdieu, 1977). Practice became the central concept in the emerging critical realist view of social science, coming into sharp focus with the work of Theodore Schatzki, as Georg Loscher, Violetta Splitter and David Seidl discusses in the chapter on 'Theodor Schatzki's theory and its implications for Organization Studies'. Practice, as an analytical category, has a long and distinguished pedigree, going back at least to analytical philosophy, especially Wittgenstein's (1968) Philosophical investigations, with its central focus on language games as forms of practical being in the world. The chapter introduces 
the practice theory developed by Theodore Schatzki and highlights its implications for organization studies. In particular, it shows how his theory, a fecund source for the 'practice turn' in organization and management theory, contributes to an understanding of the micro-foundations of organizations, the embeddedness of organizations in their wider social context, especially that there are temporal and spatial dimensions to organizations. Schatzki bases his work on a critique of Bourdieu and Giddens, two prominent practice-oriented theorists (Schatzki, 1996) to develop a version known as Site Ontology (Schatzki, 2002) that offers a general theoretical apparatus for examining the relationship between human activity and the social. For Schatzki, there is just one level of social reality, such that no distinction should be made between micro and macro levels. All human activity and social phenomena are situated within intertwined practices and it is to the practices that constitute these that we should attend.

Bourdieu, as we have seen, began his research career as an anthropologist. So too did Mary Douglas, another influential source of organization and management theorizing, as Dean Pierides and Graham Sewell elaborate in their contribution to the book, 'Mary Douglas and institutions'. In their chapter, they demonstrate how those many researchers that claim an interest in institutions and institutional theory should read and use the work of Mary Douglas. Douglas, as with other social theorists we have encountered, such as Giddens and Archer, saw one of the central problems of social theory to be the extent to which the structure of institutions and organizations determines the agency afforded to individuals. Douglas deals with institutions in a way that is quite distinctive from the latent structural functionalism that characterises many institutional theories in the management and organization studies field. She does this by way of a framework termed Grid-and-Group, 
which allows her to develop critiques of rational agency and methodological individualism. Her concerns build on the anthropological tradition of Durkheim \& Mauss (1963) and focus on the ways in which classifications are social conventions. Douglas extends their analysis of classifications to the modern world. What needs to be understood in any specific analysis is how a classificatory enterprise is matched with social requirements. In building this understanding, she draws on the work of the educational sociologist, Basil Bernstein, with his work on elaborated and restricted linguistic codes. These constitute different values, divisions of labour and social organization that are differently upheld depending on the culture that produced them as classification systems. In Douglas' work, as they explain, this is developed through the concepts of 'group' as the experience of a bounded social unit whose identity is expressed through ritual. Group is independent of what Douglas calls 'grid', which consists either of rules prioritizing the individual as a nodal point from which relations radiate or placing them within a cross-hatching of rules, distinctions and regulations. As they explain, this sets up three conditions: group and grid, in which boundaries and internal order are well established; group not grid, where boundaries are rigid but there is internal disarray and, grid not group, where ego-centred networks prevail. Students of Douglas' were subsequently to use these distinctions to generate a complete theory of Organizing and disorganizing (Thompson, 2008), the implications of which have been largely neglected. Organizational scholars, Pierides and Sewell argue, could benefit greatly from exploring how Douglas' cultural theory can be used to investigate how membership of social entities such as organizations involves a consideration of actions that are more than the enactment of schemas or logics, as organization institutionalists tend to argue. 
Several scholars have focused on what they see as the key characteristics of contemporary times; for both Luhmann and Castells, although in different ways, it is the central issue of communication and its networks. Cátia Miriam Costa, Tiago Lima Quintanilha and Sandro Mendonça address the work of Manuel Castells, who has written extensively about the 'network society'. While Luhmann was very much a systematic and Germanic theorist of systems as an ontological totality Castells was both theoretically sophisticated and open to the empirically changing world he experienced, from the "Events of May, 1968" in Paris, a proto-revolutionary context harking both backwards to a fading industrial capitalism and forwards to a world yet to come that the students on the streets would help prepare, if not make, one marked by the material revolutions of the information age.

Castells is a Catalonian, educated in France during the events of '68, a student of Alain Touraine, who was a major social theorist of post-industrial society (Touraine, 1971), who works in the United States but plays a global intellectual and policy-related role. Castells' central interest is in communication and access to information. Understanding how the social appropriation of information and communication technologies came to define the contemporary period is his central research theme. Castells' social theory provides intellectual tools with which to focus on the processes of structural transformation that have been transformational from the late 60 s to the present day. Castells key object of analysis is the "Network Society"(Castells, 1996; 2002; 2005; 2012). Networks are the defining media of power relations and communication in contemporary times; power relations are also central to Castells' (2009; see Clegg 2010) work. Networks have no centre but they do have nodal points and these are increasingly subject to the control on a small number of global multinational companies, behemoths of the contemporary scene, many of 
them media organizations. Informationalism, the result of the complex interaction of technology and society that took shape from the 1970s has served these behemoths well. Informationalism refers to the broad template of patterns and dynamics that define the Information Age, the successor to the modern times of industrial capitalism. The augmentation of human capacities for information processing and communication made possible by microelectronics, computing, software, the Internet and other revolutionary technologies has served these businesses well.

States are no longer the only major crucibles of power as networks become the prime locus for contemporary analysis of global power, laced as multiple, overlapping, open and sociospatially interactive systems comprising interconnected nodes. Communication flows through these nodes, revolutionized since the development of digital technologies, creating the global network society in its interactions and exchanges with, as well as its marginalization of, already existing societal sites, cultures, organizations and institutions of various types. The nodes configure power relations. Power relations have a structural architecture, expressed in terms of spatial and temporal orderings, focused on the extraction and appropriation of value conceived in terms of various logics that are themselves an expression of power. Behind his theorizing is an irreducible commitment to the value and values of life itself as the ultimate value on which any form of human organization should be judged.

Castells is a major figure in global social science while Nikolas Luhmann is a major figure in German social science whose ideas, although influential in Scandinavia and Germany, were been less so elsewhere until relatively recently. He is famous for his construction of a total and coherent theorizing of modern society as a system built around communication 
networks endowed with their own rules and codes, as Xavier Deroy explores in his chapter, 'Luhmann and Organizations as Social Systems'. The system was the major device of Talcott Parsons' (2013) structural functionalism, with which Luhmann was deeply familiar but does not follow. For Parsons modern societies were unified and ordered by a central value system and commonly patterned variables that all sub-systems had to deal with as institutional questions. Luhmann sees disorder and differentiation as more characteristic of modern societies in which communication is embedded within many specific, differentiated and fragmented social systems, each with specific discursive codes, which makes coordination difficult. Communication that is framed intra-systemically in a society of many systems creates a fragmented society of social systems centred on their inherent practices but not necessarily capable of communicating easily across distinct systems. Each specific type of social system's communication is structured by their respective codes, elaborated within the system and by reference to the system. In this context, diverse communication networks have no centre but systematically make up the complexity of modern societies, a complexity that may generate unexpected social evolutions. For instance, an event such as a referendum can become the occasion for unanticipated social evolutions flowing from a single decision point that summarily condensed all systemic complexities into a single binaryism: a referendum such as Brexit is an event whose binaryism has generated enormous amounts of uncertainty unforeseen in advance.

Typically, it is organizations that constitute stable units in modern societies and are characterised by decisions, designed as communication operations that typically provide structures and rules communicated by organizations to their members to reduce unexpected decisions. However, risk is an inherent element of organization's systemic 
functioning, based on communication operations. It arises when events occur that cannot be coded on the basis of precedent and rules, thus creating situations in which the structures and rules communicated by organizations to their members do not reduce unexpected decisions. A national referendum that is not bounded within existing organization systems (such as political parties or other organizations) poses such an event, as the United Kingdom experienced in the wake of the Brexit decision, from which it emerged decidedly less united. From Luhmann's perspective, risk is an inherent element of organizational systemic functioning based on communication operations but because systems have reflexive capabilities, which he calls autopoiesis, meaning that they can reproduce, repair and maintain their functioning, risks can be a source of learning how to manage better.

Organizations reduce the risks associated with the contingency of their operations of communication and absorb uncertainty derived from these operations, through hierarchies, decision premises and membership. Hence, organizations can achieve a partial reduction of uncertainty but uncertainty is everlasting if only because each new decision cannot be guaranteed to account for its interpretation on future occasions and for future events. Everlasting uncertainty is irreducible. Paradoxically, organizational decisions can also reintroduce unexpected and worrying social evolutions. With his social systems theory, Luhmann provides an approach in which events and contingency are at the centre of modern societies based on communication.

Luhmann, as a theorist of the system, might seem to be about as far from Foucault as one can possibly imagine, although in his early work, especially The Archaeology of Knowledge (1972), Foucault proved capable of producing a complex closed system of communication. 
Nonetheless, if not for this work, Michel Foucault is probably the most celebrated and famous of the social theorists discussed in this book. Foucault was a philosopher and historian of ideas whose empirical data were documentary materials, often archival. His overall concern was with different modalities of power its variation in history and in society as constituted by discourse and practice. Foucault distinguishes between sovereign power and disciplinary power. The former expresses itself through ceremony, the latter through routines and knowledge production that is expressed as a form of disciplinary power that structures the individuals' dispositions and lifeworld. In the neoliberal age, however, it is knowledge about populations and human behaviours that support a specific practice of government that Foucault calls governmentality.

Foucault, as with many of the social theorists discussed here, is not easily contained within any singular account of his work as a unity. As Alan McKinlay and Eric Pezet state in their chapter, 'Organizing Foucault: Power, Knowledge and Governmentality', there are many Foucault's: in different periods in his career he focused on discourse and archaeology, discipline and genealogy, as well as towards the end of his life, ethics and identity. The focus of the chapter, however, as the title indicates, is on Foucault the theorist of power, which treats his ideas as they were constituted historically. The explicit concern with power in Foucault's work is elaborated in Discipline and Punish (1975), a book that begins by juxtaposing two historical documents. It begins with a contemporary account of the execution of Damiens, who attempted regicide on the King of France. Robert-François Damiens was a domestic servant whose attempted assassination of King Louis XV in 1757 culminated in his notorious and controversial public execution. He was the last person to be executed in France by drawing and quartering, a gruesome description of which forms 
the core of he documentary account. This account is immediately followed by the rules of a model prison for young offenders from eighty years later that consist of a detailed timetabling of the offenders daily activities. As Foucault states, a public execution and a timetable each define a distinct penal style; each has a distinct modality of power. In the execution, power is wreaked on the body of the offender in a way that symbolically and ceremoniously represents retribution for the offence to the sovereign; in the prison, it is bureaucratically regulated. The execution represents ceremonial sovereign power; the timetable represents a productive, prosaic and everyday practice of disciplinary power.

The chapter explores the characteristics of sovereign power through analysis of lectures that Foucault gave at the College de France in 1973. Sovereign power belongs to a set of absolutist powers embedded in a historical epoch that is now past but that does not mean that sovereign power died with the birth of modern republicanism and constitutional monarchy. It is still inscribed in those moments of high ceremony and ritual when an event such as an Apple product launch is orchestrated or a famous fashion designer launches their collection of haute couture. These are relatively special events, marked as such by ceremony and the positioning of the definer or CEO as sovereign over that they have displayed; however, while sovereign displays of power are rare and rather staged, disciplinary power is embedded in the routines of everyday work and life, much as the timetable. Disciplinary power is imbricated in the most mundane moments of everyday work and life; embedded in diverse forms of surveillance that make of us knowingly subjected subjects, a theme that is explored in the chapter through consideration of the madness of King George III and the subordination of sovereign power to tight management and close surveillance during his bouts of ill health that was embedded in a fusion of power over the patient with knowledge 
codifying courses of treatment of the illness. The new power/knowledge became institutionalized in the practices of the asylum.

These practices of the asylum, much as the practices of the prison, formed a distinct regime of disciplinary power/knowledge, that were themselves characteristic of many practices developing in distinct spheres: schools, factories, hospitals, asylums, all with their distinct but family-related modalities of disciplinary power/knowledge, the very model of which Foucault found in Bentham's recourse to panopticism. In the modern era, however, while these disciplinary practices are still very evident, the modalities of power have grown to incorporate forms of governmentality that manage people through their freedoms, as McKinlay and Pezet go on to articulate. The relevancies for an understanding of contemporary managing and organizing should be evident.

The relation between Foucault's oeuvre and that of Critical Theory has been frequently discussed, probably most thoroughly by Mitchel Dean (1994). Critical theory emerged from a particular place and time in history: it was initially developed by a group of German intellectuals in the inter-war period amidst the collapse of the Weimar republic and the rise of fascism. Not all of them survived the latter, although several managed to escape the holocaust that was to consume so many and arrived in the United States where they continued their work in a very different conjuncture. As Marxist intellectuals, they were confronted by a Europe traumatized by what seemed to be the failure of the Marxist project in the Soviet Union under the tyranny of Lenin and Stalin and the rise of fascist barbarianism in Germany, in the United States they found a very different 'new world'. In Europe, as Edward Granter notes in his chapter on 'The Frankfurt School and Critical Theory', they were confronted with what Max Horkheimer and Theodor Adorno (2002), a leading member of 
the Frankfurt School, referred to as barbarism, a world scarred by unemployment, economic crisis, militarization and a terrorist regime; arriving in America in 1937, they arrived in a country that despite the depression of the earlier 1930s, appeared by contrast to be a land of plenty.

In America they did not surrender their critical analysis of social order. As critical scholars they took nothing for granted but sought to understand forms of social ordering in terms of their human potential for emancipating human beings from oppression, whether material or cultural. Indeed, the focus on the latter came to characterize the Critical Theorists' concerns, perhaps best seen in Marcuse's (1964) One Dimensional Man, a trenchant critique of consumerist society and its satisfactions, that was quite influential in various student movements of the late 1960s. Other elements of Critical Theory have been adopted and adapted in organization analysis as Granter explains, often in terms of Adorno's (1973) conception of negative dialectics: a commitment to not taking for granted the ways in which powerful interests in the world represent its nature, essence and being; the necessity of opposing ways of thinking in which analysis and everyday life can become trapped in the repletion of mundaneity without ever aspiring to transcend and improve its quality.

One area that the Critical Theorists have been, in turn, criticized for, is their lack of attention to certain facts that sustained the capitalism they critiqued:

Frankfurt School critical theory, despite its seminal insights into the relationships between domination, modern society, and the opportunities for redemption through art as critique, is stunningly silent on racist theory, anti-imperialist resistance, and oppositional practice in the empire (Said, 1993, p. 278).

Others with an interest in emancipation might have seen further areas in which blindness was apparent. One of these was feminism, a perspective that the relative gender blindness 
of the student movements inspired by critical theory, did much to provoke. Other forms of social theory were to prove more useful in this respect. Judith Butler's particular interest is in gender classifications and an approach to them that is developed in part from Foucault, although she also shares a common interest with Douglas in the ways that classifications work. Kate Kenny, in her chapter on 'Judith Butler and performativity', explores her approach to studying identification and subjection in organizations, focusing especially on her theory of performativity. Butler's work develops out of her commitments as a feminist, examining discourses of gender and sexuality and how these play out in social life, including how they interact with each other.

In theorizing new directions for understanding identification, Butler's work followed on directly from the examination of subjection to power that Foucault developed in his later work, The history of sexuality (Foucault, 1999). Butler's approach to identification and subjection is conceptualized in terms of affective recognition, which describes how we are compelled, affectively and often without our knowledge or will, into subjection to powerful discourses. These ideas become particularly evident when we look at the ways in which gender emerges as a classificatory system of recognition; not only does such a system have importance for understanding socialization process (Allen, 2013) but it is also important for organization studies, in particular for studies of identification and subjection and the role of power in such processes. The subject emerges through the positions available and afforded in language, outside of which one cannot exist. Those norms with which we identify compel us to seek recognition in their terms; to be considered as well as to consider oneself as a valid subject one must be legitimized by the normative identities available. Power relations and their manifestations as normative categories dictate how subjects may be recognized. 
Our compulsion to be recognized can be productive in many cases and for example leads to the formation of solidarity groups but it can so lead to othering and exclusion of those constituted as others. Affective recognition, it is concluded, is ultimately ambivalent because the power of norms is neither determined nor monolithic but is always open to being subverted: the engagement of structure and agency is never ending.

Many of the theorist that we have considered thus far focus extensively on the duality of agency and structure. Norbert Elias, the subject of Robert van Krieken's chapter on 'Norbert Elias and organizational analysis: towards process-figurational theory', does not dwell on dualities. Elias' approach to analysis is deeply grounded in mastery of historical materials. Being so embedded in historical documents, such as manuals of etiquette and manners, Elias can hardly fail to take a processual approach, one that van Krieken terms a 'processfigurational' approach. At times, Elias' approach might seem far from contemporary concerns: the history of the civilizing process, the emergences of courtly society and the transformation of its norms, detailed analysis of table manners and arrangements: these are distinctive themes seemingly far from contemporary concerns with management and organizations. Not so, suggests van Krieken: he has much to offer. There are links with Weber's rationalization thesis (which immediately draws links to Ritzer's (2002) McDonaldization thesis); the importance of self-censorship as an institutionalized mode of psychic control has echoes in Foucault (1975), as does his insistence on a relational conception of power. The concept of figuration covers similar ground to that staked out in actor network theory. Elias was discussing habitus before Bourdieu (1977).

Elias' approach is both processual, that is historical, and relational, that is focused on social relations rather than static entities, expressed in concepts that are invariably reifications. In 
this respect he shares a preference with Karl Weick (1995) for verbs as gerunds rather than for nouns. Focusing on the gerund form of verbs immediately orients us to social action, rather than to social structure; structure becomes contingent on doing rather than being. It's being there is always an accomplishment constituted in action. The apparent independence of social order and social structure from intentional human action is an appearance that much relational work sustains; the task of social research is to make this relational work not so much apparent as transparent. In doing so the figurations that sustain social relations and the structures they assume and presume become the matter for analysis. A central figuration of modern times, of course, is the notion of the organization and its management and as van Krieken argues, it is through close attention to phenomena such as the emergence of norms of meetings, protocols, dress and control of emotionality, that we can bring Elias' perspective to bear on analysis. Indeed, as he charts in the chapter, there are many contributions that have made major contributions using Elias as a resource, although they seem not to have been incorporated into mainstream theorizing.

Norbert Elias shared some characteristics with another of our cast of characters: he was an involuntary outsider who adopted another country for his professional life. Elias, of Jewish descent, was born in Bresslau in Germany in 1897. In the 1930s he was working under Karl Mannheim at the Institute of Sociology in the University of Frankfurt, which was closed down by the fascists in 1933. Sensing the future of things to come, Elias fled, initially to Paris, eventually to England, where he reconnected with Manheim, to work with him at the London School of Economics before being interred as an enemy alien during part of the war. Later, he was to join the University of Leicester Sociology Department, in 1957, where he stayed until his retirement. It was only several years after his retirement that he became 
well known outside of Leicester, when his study of The Civilizing Process (Elias, 1969) was published. It was a career whose trajectory one would be unlikely to find in these days.

The other involuntary outsider was Zygmunt Bauman, a Polish émigré sociologist who spent most of his career in England, working at the University of Leeds in Yorkshire. He left not because of the Nazis but as a result of a political purge by the Communist authorities in his native Poland in 1968. Initially he went to live in Israel but after three years moved to England. His output of books was prodigious and in his later years they focused on the issue of what he termed 'liquid modernity'. For Bauman, the world of organizations was becoming ever more liquid, dissolving old structures, certainties and relations. Stewart Clegg and Miguel Pina e Cunha explore the contours of these liquid changes and their import for organization analysis in their chapter on 'Liquefying modernity: Zygmunt Bauman as organization theorist', by discussing liquid selves, liquid organizations and liquid aesthetics, as three facets of Bauman's work with implications for organizations and management.

Applying the metaphor of liquid to organizations highlights practices in which investments in people are highly liquid and easily liquidated, with no long-term investment implications. As the chapter explores, there are ethical, political, identity, and organizational consequences of increasing liquidity. Ethically, modern leaders are seen to be forever reassembling the pieces of their own identity as the liquid state changes. Politically, power relations become marked by a new lightness of synoptical power relations (Mathieson, 1997 for the original reference; also see Lancione and Clegg 2014) augmenting and supplementing more traditional panoptical power as we encounter it in Foucault's disciplinary power. In terms of identity, liquidity is marked by the immediateness of the self in the moment. Organizationally, liquidity predisposes its leaders to improvisation over heavy scripting as 
role prescriptions become more fluid and uncertain and events less predictable. The focus of the chapter is on how liquid modernity frames contemporary leadership. Managerial expertise in 'leadership' is increasingly seen as a practice of shared, dispersed and mutually constituted influence gained in successful steering of projects despite the irreducible contingency of unforeseen events. Rather as Luhmann sees the modern world as composed of systems of communication that are specific and differentiated Bauman is equally sceptical about the capacity of any central control to steer events. Deregulation, individualization, weakened human bonds, increased fluidity of solidarities and the drift from normative regulation through common patterns of socialization to processes that are much more individuated are all key features of the liquid condition identified by Bauman. As such, as the chapter concludes, they leave social ordering increasingly at risk from the sirens of authoritarian populism. Populism, of course, in not the only risk of contemporary times: to populism one must add climate catastrophe as a phenomenon that social theory can address to inform management and organization studies.

\section{Conclusion}

None of the social theorist surveyed here would regard managing and organizing, management and organizations, as a self-contained space of explanation that needed no reference to larger social forces and their theorization. Instead, in their different ways, they saw the field as a terrain in which rival social theories produced coherent, if diverse, insights into these wider social forces and their effects

The world is increasingly global as a result of digital affordances yet major business organizations are increasingly centralized as a result of the monopolizing tendencies 
inherent in command of these affordances. Patterns of everyday life, commerce and administration are, in Bauman's terms, increasingly liquid for the many but they are also solidifying wealth and privilege for the few. In a world in which old certainties are dissolving as fast as new opportunities emerge it is no longer the case that any organization provides boundaries strong enough to keep the uncertainties at bay nor has managers wise enough to understand the framing, transcending and upsetting of assumptions of what is normal. In such times the questioning that various social theories offer becomes ever more relevant to how we understand and live our lives, how those lives are constituted by power relations that legitimate, certain ideologies, norms, values, roles, rules, identities, beliefs, discourses, symbols, meaning-systems and systems of domination. Organizing and managing is rooted in the assumptions of everyday life that these power relations sustain. They are the matrix of normalcy, a matrix that cannot be understood through just those terms that the matrix manufactures, sustains, and reproduces. Social theories enable us to understand that the ideational citadels of knowledge need to be open to disruption just as much as are those material phenomena upon which they speculate. Social theories provide devices for disruption of extremely consequential discourses, such as management and organization theory: in the concluding chapter we invite you to explore these theories by posing an index of possibilities for future work informed by the social theories whose exploration awaits you, the reader. 


\section{References}

Adorno, T. (1973). Negative Dialectics. London: Routledge \& Kegan Paul.

Alcadipani, R., \& Hassard, J. (2010). Actor-Network Theory, organizations and critique: towards a politics of organizing. Organization, 17(4), 419-435.

Allen, A. (2013). The Politics of Ourselves: Power, Autonomy and Gender in Contemporary Critical Theory. New York: Columbia University Press.

Bateson, G. (2000). Steps to an ecology of mind: Collected essays in anthropology, psychiatry, evolution, and epistemology. Chicago: University of Chicago Press.

Bhaskar, R. (1975). A realist theory of science, Leeds: Leeds Books.

Bourdieu, P. (1977). Outline of a theory of practice. Cambridge: Cambridge University Press.

Bourdieu, P. (1984). Distinction: A social critique of the judgement of taste. London: Routledge.

Castells, M. (1996) The Information Age: Economy, Society, and Culture, Vol.1: The Rise of the Network Society. Chichester, West Sussex: John Wiley and Sons.

Castells, M. (2002). The Internet Galaxy: Reflections on the Internet, Business and Society. Oxford: Oxford University Press.

Castells, M. (2009). Communication Power. Oxford: Oxford University Press.

Castells, M. (2012). Networks of Outrage and Hope: Social Movements in the Internet Age. Cambridge, US: Polity Press. 
Carter, C. (2008). A curiously British story: Foucault goes to business school. International Studies of Management and Organization, 38(1): 13-29.

Clegg, S. R. (2010) Controlling communication and contesting conceptualization: Power in $21^{\text {st }}$ century global society, a review of Manuel Castells' Communication Power, Oxford: Polity. The Journal of Power 3(1): 142-145.

Czarniawska, B., \& Hernes, T. (2005). Actor-network theory and organizing. Copenhagen: Copenhagen Business School Press.

Dean, M. (1994). Foucault's methods and historical sociology. London: Routledge

Durkheim, É., \& Mauss, M. (1963). Primitive classification. London: Cohen \& West.

Elias, N. (1969) The Civilizing Process, Vol. I. The History of Manners, Oxford: Blackwell.

Eisenhardt, K. M. (1989). Building theories from case study research. Academy of Management Review, 14(4), 532-550.

Fei, X. (1939). Peasant Life in China: A Field Study of Country Life in the Yangtze Valley. London: Routledge \& Kegan Paul.

Foucault, M. (1972). The archaeology of knowledge. New York: Pantheon.

Foucault, M. (1975). Discipline and Punish: the Birth of the Prison. New York: Random House.

Foucault, M. (1979). The History of Sexuality Volume 1: An Introduction. London: Allen Lane.

Freire, P. (2018). Pedagogy of the oppressed. New York: Bloomsbury. 
Giddens, A. (1973). The class structure of the advanced societies. London: Hutchinson.

Giddens, A. (1976). New Rules of Sociological Method: a Positive Critique of interpretative Sociologies. London: Hutchinson.

Harré, R and Madden, E. H. (1975). Causal powers: A theory of natural necessity. Lanham, Maryland: Rowman \& Littlefield.

Horkheimer, M., Adorno, T. W. (2002). Dialectic of enlightenment. Palo Alto, CA: Stanford University Press.

Lancione, M., \& Clegg, S. R. (2015). The lightness of management learning. Management Learning, 46(3), 280-298.

Law, J. and Hassard, J. (1999). Actor network theory and after. Oxford: Blackwell.

Marcuse, H. (2013). One-dimensional man: Studies in the ideology of advanced industrial society. London: Routledge.

Marx, K. (1976). Capital, Vol. 1. London: NLB/Penguin.

Mathiesen, T. (1997). The viewer society: Michel Foucault's Panopticon revisited. Theoretical Criminology, 1(2), 215-234.

Mbigi, L. (2005). Ubuntu: The spirit of African transformation management. Randburg, South Africa: Knowres.

Parsons, T. (2013). The social system. London: Routledge.

Ritzer, G. (2004). The McDonaldization of society. Newbury Park, CA: Pine Forge Press. 
Said, E. (1993). Culture and Imperialism. New York: Knopf

Schatzki, T. R. (2002). The site of the social: A philosophical account of the constitution of social life and change. Philadelphia, PA: Penn State Press.

Schatzki, T. R. (1996). Social Practices - A Wittgensteinian Approach to Human Activity and the Social. Cambridge, MA: Cambridge University Press.

Seremani, T. W. \& Clegg, S. R. (2015). Postcolonialism, organization and management theory: The role of "epistemological third spaces". Journal of Management Inquiry, DOI: $10.1177 / 1056492615589973$.

Simon, H. A. (1996). The sciences of the artificial. Boston: MIT press.

Simon, H. A. (2013). Administrative Behavior. New York: Simon and Schuster.

Smith, A. (1950). An Inquiry into the Nature and Causes of the Wealth of Nations. London: Methuen.

Touraine, A. (1971). The Post-Industrial Society. Tomorrow's Social History: Classes, Conflicts and Culture in the Programmed Society. New York: Random House.

Parsons, T. (2013). The social system. Lisbon: Routledge.

Taylor, F. W. (1911). The principles of scientific management. New York: Harper \& Brothers.

Thompson, M. (2008). Organising and Disorganising: A Dynamic and Non-Linear Theory of Institutional Emergence and its Implications. Charmouth: Triarchy Press. 
Üsdiken, B. (2010). Between contending perspectives and logics: Organizational studies in Europe. Organization Studies, 31(6), 715-735.

Üsdiken, B. (2014). Centres and Peripheries: Research Styles and Publication Patterns in 'Top' US Journals and their European Alternatives, 1960-2010. Journal of Management Studies, 51(5), 764-789.

Üsdiken, B., \& Pasadeos, Y. (1995). Organizational analysis in North America and Europe: A comparison of co-citation networks. Organization Studies, 16(3), 503-526.

Weber, M. (1978). Economy and Society: An outline of Interpretive Sociology. Berkeley; CA: University of California Press.

Weick, K. E. (1969). The social psychology of organizing. Boston, MA: Addison-Wesley

Weick, K. E. (1995). Sensemaking. Thousand Oaks, CA: Sage.

Wittgenstein, L. (1968). Philosophical Investigations. London: Macmillan 
